\title{
Produktivitas Sapi Bali di Lahan Pastura dan Perkebunan Kelapa Sawit di Kabupaten Keerom Provinsi Papua
}

\author{
Productivity of Bali Cattle in Pastura Land and Palm Oil Plantation in Keerom District, Province of Papua \\ O. Kocu ${ }^{1}$, Salundik², R. Priyanto, I. Prihantoro ${ }^{2}$ \\ Mahasiswa Pascasarjana Program Studi Ilmu Produksi dan Teknologi Peternakan \\ Departemen Program Studi Ilmu Produksi dan Teknologi Peternakan \\ Fakultas Peternakan Institut Pertanian Bogor \\ Jln. Agatis, Kampus IPB Dramaga, Bogor, 16680, Indonesia \\ No.Telp : +62 82113846174 Email : obedkocu3@gmail.com
}

\begin{abstract}
Bali cattle are potentially developed on pasture and palm oil plantation lands. They are kept in small scale by local farmers. The study aimed to investigate the forage and bali cattle productivitie in those two grazing areas. Total land area, carrying capacity and total land capacity for bali cattle were analysed to evaluate the forage productivity of pasture and oil plantation grazing areas. A total of 60 heads of bali cattle aging 1-3 years were used to evaluate their productivities including bodyweight and linear body measurements. A number of 30 heads of the animal had been raised on pasture and the other 30 heads on palm oil plantation. The results showed that there were 7191 ha of pasture and 5519 ha of palm oil plantation that could cover grazing cattle of 28188.72 animal unit and 20585.87 animal unit respectively. The carrying capacity of pasture was slightly higher than that of palm oil plantation, which were 3.92 AU and 3.73 AU per ha per year respectively. The bali cattle, particularly female animal, raised on pasture had better productivity in term of body weight and hip height. The higher cattle productivity on pasture was due to the additional supplementation of King grass and Elephant grass. In general, the bali cattle kept in the two different raising system (pasture and palm oil plantation system) had good performance since their population were still below their carrying capacities.
\end{abstract}

\section{Keywords: Productivity, Bali Cattle, Pasture, Oil Palm Plantation}

\section{PENDAHULUAN}

Sapi bali adalah bangsa sapi daging lokal yang memiliki potensi genetik sangat baik serta keunggulan sebagai penghasil daging yang sangat potensial. Secara alami, sapi bali memiliki kemampuan beradaptasi sangat baik terhadap kondisi lingkungan tropis, sifat tidak selektif terhadap pakan, serta mampu memberikan respon pertumbuhan yang baik terhadap kondisi dan kualitas lingkungan pemeliharaan yang sederhana. Sapi bali juga sangat cocok digunakan sebagai ternak perintis di daerah Transmigrasi sehingga mendapat prioritas digunakan dalam program pengembangan lokasi transmigrasi di Indonesia (Darmadja 1980). Melihat potensinya yang unggul tersebut serta adanya kekhawatiran terhadap kemunduran mutu yang terjadi pada akhir-akhir ini, maka perlu dilakukan evaluasi terhadap permasalahan yang terjadi pada sapi bali. Di samping itu, saat ini juga dibutuhkan adanya usaha penyediaan ternak bibit sapi bali yang unggul untuk mengimbangi jumlah pemotongan atau pengeluaran yang terus meningkat jumlahnya setiap tahun. Produktivitas sapi bali sangat dipengaruhi oleh faktor pakan, daya dukung lingkungan dan pola pemeliharaan ternak mempunyai arti sangat penting dalam usaha ternak sapi yang dipelihara pada lahan pastura dan lahan perkebunana sawit, karena ketiga hal tersebut erat hubungannya dengan kemampuan ternak untuk menghasilkan pertumbuhan dan bobot badan yang efisien. Potensi lahan pastura dan perkebunaan kelapa sawit di Kabupaten Keerom Provinsi Papua yang sangat menjanjikan untuk pengembangan sapi potong belum dimanfaatkan secara maksimal namun potensi pakan yang berlimpah belum didukung oleh pola pemeliharaan pada lahan pastura dan sistem integrasi sawit sapi yang baik sehingga perlu adanya pengembangan riset dalam rangka menghasilkan output bagi pemerintah daerah maupun petani peternak dalam rangka upaya peningkatan populasi dan produktivitas ternak sapi bali serta peningkatan mutu dan kualitas pakan yang mendukung usaha peternakan sapi pada lahan pastura maupun perkebunan kelapa sawit di 
Kabupaten Keerom.

Berdasarkan hal tersebut di atas maka dilakukan penelitian yang bertujuan untuk menganalisis aspek lingkungan, pakan dan SDM petani peternak dalam mendukung produktivitas ternak sapi bali pada areal lahan pastura dan lahan perkebunan kelapa sawit di Kabupaten Keerom Provinsi papua.

Kabupaten Keerom merupakan daerah pengembangan kelapa sawit yang luas di Provinsi Papua dan dapat dimanfaatkan sebagai lahan penggembalaan ternak sapi, karena di perkebunan kelapa sawit banyak pakan ternak yang tumbuh disekitar kelapa sawit seperti: kacang-kacangan (leguminose), lamtoro, kolonjono, daun dan biji-bijian kelapa sawit. Oleh sebab itu, integrasi kelapa sawit dengan ternak sapi sangat cocok untuk dikembangkan di areal perkebunan kelapa sawit yang ada di Kabupaten Keerom. Selain itu luas lahan kelapa sawit di Kabupaten Keerom yang merupakan kegiatan perkebunan memiliki areal lahan terluas yaitu lebih dari 47.986,98 ha atau mencapai (99\%) luas lahan tanaman Perkebunan di Kabupaten Keerom dan sektor pertanian memiliki luas lahan 4.056 ha atau $(0,47 \%)$ dari luas lahan pertanian sebagai pertanian lahan kering (BPS Keerom 2014).

Luasnya lahan perkebunaan kelapa sawit dan pertanian tanaman pangan di Kabupaten Keerom memberikan peluang bagi sumber pakan ternak yang berlimpah berasal dari sisa hasil pertanian dan perkebunaan kelapa sawit serta rumput dan legum yang tersedia pada sela-sela tanaman sawit dan lahan pertanian sangat mendukung dalam peningkatan produktivitas ternak sapi.

Masuknya ternak sapi bali di Provinsi Papua melalui Program Bantuan Presiden (Banpres) tahun 1970an. Kabupaten Keerom sebagai salah satu wilayah penyebaran ternak seiring dengan masuknya program transmigrasi sehingga laju pertumbuhan populasi dan Produksi ternak tidak seiring dengan laju pertumbuhan konsumsi dan pertambahan penduduk di Kabupaten Keerom yang semakin cepat dengan jumlah penduduk saat ini mencapai 53.002 jiwa.

Pengembangan sekarang beralih ke Wilayah Timur Indonesia melalui pengembangan peternakan sapi Bali di Indonesia Timur yang mencakup dua Provinsi yaitu Provinsi Papua dan Provinsi Papua Barat, juga masih mengalami banyak kendala terutama terbatasnya bibit sapi bali baik dari segi kuantitas dan kualitas genetik. Sekitar 90\% ternak sapi potong di wilayah Papua dan Papua Barat di dominasi oleh ternak sapi lokal yaitu sapi Bali. Sampai saat ini dinas terkait untuk memenuhi kebutuhan bibit sapi Bali bagi para peternak masih mendatangkan dari luar Papua, seperti Nusa Tenggara Timur, Nusa Tenggara Barat, Bali, Jawa Timur dan Pulau Seram. Sesuai dengan data Dinas Peternakan Provinsi Papua bahwa populasi sapi bali di Provinsi Papua pada tahun 2014 berkisar antara 94.865 ekor. Pengembangan sapi bali terbanyak ada di Kabupaten Merauke, Kabupaten Keerom, Kota Jayapura, Kabupaten Jayapura, Nabire, Sarmi dan Biak Numfor. Data Dinas Pertanian, Peternakan dan Perikanan Kabupaten Keerom populasi sapi di Kabupaten Keerom pada tahun 2014 berkisar antara 13.634 ekor.

Kabupaten ini merupakan salah satu daerah yang lebih cocok untuk tanaman pertanian seperti: jagung, kacang kedelai, kacang tanah, singkong, padi dan umbiumbian. Hasil pengamatan bahwa sebagian besar petani yang memiliki ternak kondisi ekonominya lebih baik dibanding dengan petani yang tidak memiliki ternak. Pembangunan subsektor peternakan di Kabupaten Keerom masih cukup penting untuk memenuhi kebutuhan ternak daerah lain, disamping untuk memenuhi konsumsi sendiri.

\section{MATERI DAN METODE}

\section{Waktu dan Tempat Penelitian}

Penelitiandilaksanakan pada bulan Oktober sampai Desember 2016 di Kabupaten Keerom Provinsi Papua. Penelitian hijauan pakan dilakukan di Laboratorium Agrostologi dan Ilmu Nutrisi Pakan, Departemen INTP, Fakultas Peternakan IPB.

\section{Bahan dan Peralatan}

Bahan yang digunakan adalah sapi bali kisaran umur 1-3 tahun. Peralatan yang digunakan adalah termometer, GPS, tongkat ukur, pita ukur, timbangan digital, hijauan pakan.

\section{Peubah yang diamati}

\section{Ketinggian Tempat, Suhu Udara, Kelembapan, Curah Hujan dan THI}

Ketinggian tempat diukur menggunakan GPS. Data suhu udara pada lahan pastura dan lahansawit diukur menggunakan thermo meter. Pengukuran dilakukan tiga kali sehari yaitu pagi pukul 7.30 WIT, siang pukul 13.30 WIT dan sore pukul 17.30 WIT. Data kelembaban udara dan curah hujan tahun 2016 diperoleh dari Badan Meteorologi dan Geofisika Wilayah V Jayapura. Temperatur humidity index (THI) rata-rata harian diperoleh dengan menggunakan formulasi Handoko (1995) sebagai berikut:

$$
\text { THI : 0,4(Tdb+Twb)+15 }
$$

Keterangan :

THI : Temperature Humidity Index

$\mathrm{Tdb}$ : Temperatur bola kering $\left({ }^{\circ} \mathrm{F}\right)$

Twb : Temperatur bola basah $\left({ }^{\circ} \mathrm{F}\right)$

\section{Ukuran Tubuh dan Bobot Badan}

Data ukuran tubuh yang diukur adalah tinggi pundak, panjang badan, lingkar dada, lebar dada, dalam dada, tinggi pinggul dan bobot badan sapi bali pada lahan pastura dan lahan sawit.

\section{Rancangan Percobaan dan Analisis Data}

Penelitian ini disusun menggunakan rancangan acak lengkap (RAL) dengan dua taraf perlakuan yaitu lokasi lahan pastura dan lahan sawit. Pengaruh perbedaan lokasi terhadap produktivitas sapi bali umur 1-3 tahun sebanyak 60 ekor yang terdiri dari $\mathrm{I}_{0}$ : umur 1-1.5 tahun, $\mathrm{I}_{1}$ : umur 1,5-2 tahun dan $\mathrm{I}_{2}$ : umur 2-3 tahun. Masing-masing tediri atas 20 ekor sapi bali. Data yang diperoleh dianalisis menggunakan analisis ragam (ANOVA) dan uji lanjut 
menggunakan least sguare means untuk mengetahui beda perlakuan menurut Ahmad et al. (2002), untuk mengetahui pengaruh perbedaan lokasi pemeliharaan uji lanjut menggunakan T-Tes menurut Nurgiantoro et al. (2002).

\section{HASIL DAN PEMBAHASAN}

\section{Ketinggian Tempat}

Ketinggian tempat dari permukaan laut secara umum di Kabupaten Keerom berkisar antara 0-2000 mdpl khusus lokasi penelitian Distrik Skanto, Arso dan Arso Timur ketinggian berkisar antara 0-1500 mdpl BPS Keerom (2016). Rataan ketinggian tempat, suhu udara,kelembapan udara, curah hujan dan THI berdasarkan hasil pengukuran disajikan pada Tabel 1 .

Lokasi pengambilan sampel lahan pastura ketinggian tempat 71,33 mdpl dan lokasi sawit 51,0 mdpl atau kedua areal lahan penggembalaan tergolong berada pada dataran rendah dan beriklim basah sehingga daerah ini sering terjadi bencana banjir ketika musim hujan. Lokasi Penelitian Distrik Arso, Skanto dan Arso Timur tergolong dataran rendah dan memiliki permukaan tanah yang sejajar dengan permukaan laut sehingga arus balik dari aliran sungai sering mengakibatkan banjir pada musim hujan (banjir tahunan) menimbulkan endapan lumpur sehinggamenjamin vegetasi rumput alam dapat tumbuh subur pada lahan penggembalaan secara kontinuitas dapat menjamin kebutuhan pakan ternak sepanjang tahun.

Hal ini merupakan faktor lingkungan yang secara alami dapat mendukung produktivitas pakan secara kualitas, kuantitas dan kontinuitasmenjamin produktivitas ternak yang dipelihara pada lahan pastura maupun lahan sawit. Rusdin et al. (2009) semakin tinggi tempat maka suhu akan semakin rendah. Makin tinggi suatu tempat variasi temperatur akan semakin besar meskipun temperatur musim pada siang hari tidak besar.

\section{Suhu Udara dan Kelembaban Udara}

Suhu udara yang diperoleh dari hasil pengukuran lapangan lahan pastura $28,9^{\circ} \mathrm{C}$ dan lahan sawit $28^{\circ} \mathrm{C}$ (Tabel 1). Dari perbedaan suhu udara pada kedua areal lahan penggembalaan yang tidak berbeda tidak dapat menimbulkan cekaman terhadapat ternak sapi bali pada kedua areal dan ternak berada pada kondisi nyaman (comfort zone). Bangsa sapi peranakan ongole, sapi bali, sapi Brahman dapat beradaptasi dengan baik pada lokasi dengan suhu udara $24-34^{\circ} \mathrm{C}$ tetapi tidak beradaptasi pada

Tabel 1. Ketinggian tempat, suhu udara, kelembapan udara, curah hujan dan THI

\begin{tabular}{lcc}
\hline Keterangan & \multicolumn{2}{c}{ Lokasi pemeliharaan } \\
\cline { 2 - 3 } & Lahan Pastura & Lahan Sawit \\
\hline Ketinggian Tempat (mdpl) & 71,33 & 51,0 \\
Suhu Udara $\left({ }^{\circ} \mathrm{C}\right)$ & 28,9 & 28,0 \\
Kelembapan Udara (\%) & $82,9^{*}$ & $82,9^{*}$ \\
Curah Hujan (mm) & $240,5^{*}$ & $240,5^{*}$ \\
THI & 78,6 & 78,0 \\
\hline
\end{tabular}

Sumber : * BMG (2016) suhu dibawah $24^{\circ} \mathrm{C}$ (BQA 2014).

Kelembaban udara pada lokasi penelitian berdasarkan hasil pengukuran (Tabel 1) rata-rata 82,9\%. Yani et al. (2006) mengatakan bahwa kelembaban harian di Indonesia umumnya tinggi yaitu $60-90 \%$. Hal tersebut dapat mempengaruhi tingkat produktivitas sapi. Ternak sapi bali pada kedua areal mengalami cekaman ringan apa bila terjadi musim panas yang menimbulkan kelembaban udara tinggi dan ternak dapat nyaman apabila kondisi lingkungan terjadi hujan temporer sehingga kondisi kelembaban udara tergolong rendah dan akibat cekaman panas yang ditimbulkan dari tubuh ternak berkurang sehingga ternak berada pada kondisi nyaman (comfort zone). Sapi bali yang digembalakan pada kedua areal lahan penggembalaan pada musim kemarau dapat merumput pada pagi dan sore hari dan beristirahat pada siang hari, apa bila musim hujan ternak dapat merumput sepanjang hari dan beristirahat pada malam hari untuk melakukan penyesuaian secara fisiologis dan secara tingkah laku (behaviour) terhadap lingkungan.

\section{Temperatur Humidity Index (THI)}

Hasil perhitungan Temperatur Humidity Index (THI) merupakan hubungan besaran antara suhu dan kelembapan udara tertinggi pada kedua areal lokasi lahan pastura dan lahan sawit (Tabel 1). Nilai THI yang diperoleh pada lahan pastura 78,6 dan lahan sawit 78,0 sehingga dapat disimpulkan bahwa nilai THI pada kedua areal berada pada zona kuning cerah yang menunjukan bahwa sapi mengalami stress ringan (alert zone) yang terukur pada nilai THI.

BQA (2014) membagi nilai THI untuk sapi potong menjadi 4 zona yaitu : zona putih dengan nilai THI 69-74 sapi dalam kondisi normal, Zona kuning cerah nilai kisaran THI 75-78 dan sapi diduga mengalami stres ringan (alert zone). Zona kuning gelap dengan kisaran nilai THI 79-83 sapi diduga mengalami stress sedang (danger zone) dan Zona terakhir adalah Zona merah dengan nilai THI pada kisaran 84-97 dan sapi diduga mengalami stress berat (emergency zone).

\section{Kapasitas Tampung}

Hasil penelitian menunjukan bahwa nilai kapasitas tampung ternak pada lahan pastura adalah 3,92 ST/ha/tahun dengan kebutuhan lahan $0,26 \mathrm{ha} / \mathrm{ST} /$ tahun. Lahan sawit 3,73 ST/ha/tahun dengan kebutuhan lahan 0,26 ha/ST/tahun. Reksohadiprojo (1981) bahwa suatu padang penggembalaan dinyatakan produktif apabila mempunyai daya tampung 2,5 $\mathrm{ST} / \mathrm{ha} /$ tahun dengan demikian maka daya tampung lahan pastura maupun lahan sawit di Kabupaten Keerom saat ini lebih tinggisehingga dapat disimpulkan bahwa secara umum kualitas dan kuantitas padang penggembalaan pada kedua areal lahan penggembalaan berada pada under grazing dan peningkatan populasi ternak pada kedua areal lahan penggembalaan tersebut masing-masing perlu dapat ditingkatkan.Hasil penelitian menunjukan bahwa nilai kapasitas tampung lahan pastura saat ini 1 ha dapat menampung 3,92 ekor ternak sapi total luas lahan yang tersedia saat ini 7.191 dapat menampung 28.188,72 ekor ternak sapi bali dan baru terisi populasi ternak riil 
Tabel 2. Kebutuhan lahan dan kapasitas tampung ternak pada lahan pastura dan lahan sawit

\begin{tabular}{lcc}
\hline Keterangan & \multicolumn{2}{c}{ Sistim Pemeliharaan } \\
\cline { 2 - 3 } & Lahan & Lahan \\
& Pastura & Sawit \\
\hline Kebutuhan lahan ha/ST/tahun & $0,26 \pm 0,01$ & $0,26 \pm 0,10$ \\
Kapasitas Tampung ST/ha/tahun & $3,92 \pm 0,17$ & $3,73 \pm 0,11$ \\
Total luas lahan (ha) & 7.191 & 5.519 \\
Daya Tampung lahan (ST) & $28.188,72$ & $20.585,87$ \\
Populasi Riil (ST) & 9.517 & 5.519 \\
\hline
\end{tabular}

Sumber : Data primer

saat ini 9.517 ekor dan kekurangan populasi ternak yang perlu ditambah sebanyak 18.671,72 ekor. Hasil penelitian ini kapasitas tampung lebih tinggi jika dibandingkan dengan penelitian Rauf (2015) kapasitas tampung lahan penggembalaan di Bombana 1,50 ST/ha/tahun dan kebutuhan lahan 0,66 ST/ha/tahun, Yoku (2012) padang penggembalaan alam di Kebar Papua Barat 0,48-1,70 UT/ ha/tahun, Rusdin et al. (2009) padang penggembalaan alam di Lore Tengah $0,84 \mathrm{ST} / \mathrm{ha} /$ tahun dan $0,56 \mathrm{ST} / \mathrm{ha} /$ tahun. Gambaran kebutuhan lahan dan kapasitas tampung ternak lahan pastura dan lahan perkebunan kelapa sawit (Tabel 2).

Lahan sawit 1 ha dapat menampung 3,73 ekor ternak sapi bali dengan total luas lahan yang tersedia saat ini 5.519 ha dapat menampung 20.585,87 ekor ternak populasi ternak riil saat ini baru terisi 5.519 ekor kekurangan populasi ternak yang perlu ditambah sebanyak 15.066,87 ekor. Daya tampung lahan perkebunan sawit di Kabupaten Keerom masih lebih tinggi dari hasil penelitian Farizaldi (2011) pada perkebunan sawit berbagai umur di Kabupaten Batanghari Provinsi Jambi kapasitas tampung 0,4-0,22 ST/ha/tahun. Talib et al. (2015) bahwa produktivitas perkebunan sawit rakyat tanaman antara tanaman sawit tertinggi pada sawit berumur tiga tahun dengan daya tampung 1,44 ST/ha/tahun dan sawit umur enam tahun menurun menjadi $0,71 \mathrm{ST} / \mathrm{ha} /$ tahun.

\section{Komposisi Kimia Hijauan}

Komposisi kimia sampel hijauan pada lahan pastura dan lahan sawit (Abu, Lemak, Protein dan Serat kasar) yang terkandung dalam hijauan yang tumbuh pada kedua areal. Hasil analisis proksimat rumput lapangan pada lahan pastura dan lahan sawit di Kabupaten Keerom Provinsi Papua (Tabel 3) menunjukan bahwa lahan kelapa sawit memiliki komposisi kimia pakan lebih tinggi dari lahan pastura. Berdasarkan hasil analisis laboratorium disajikan pada Tabel 3.

Hasil ini lebih tinggi dari penelitian Taufan et al. (2014) tentang potensi hijauan pada perkebunan kelapa sawit protein berkisar antara 8,25-10,5\%, lemak 2,44,2\%, serat kasar 22,43-23,2\%, abu 2,48-3,98\%. Rusdin et al. (2009) protein berkisar antara 3,10- 5,89\%, lemak 2,0-2,99, serat kasar 34,89-40,68. selanjutnya menurut Rusdin padang penggembalaan alam di lore tengah memiliki komposisi kimia pakan yang lebih rendah protein 3,10-5,89 lemak 2,00-2,99 abu 4,10-6,29 dan serat kasar $34,89-40,68$. Tingginya kandungan zat pakan pada lahan
Tabel 3. Komposisi kimia hijauan pada lahan pastura dan lahan sawit

\begin{tabular}{lcc}
\hline Komposisi kimia & \multicolumn{2}{c}{ Sistem pemeliharaan } \\
\cline { 2 - 3 } & Lahan pastura & Lahan Sawit \\
\hline & & \\
Abu (\%) & 7,49 & 7,76 \\
Lemak (\%) & 1,16 & 1,59 \\
Protein (\%) & 7,28 & 12,92 \\
Serat kasar (\%) & 25,04 & 30,57 \\
\hline
\end{tabular}

Sumber : Data primer

perkebunan kelapa sawit di Kabupaten Keerom disebabkan oleh beberapa faktor diantaranya, Tanaman pakan yang tumbuh pada lahan perkebunan kelapa sawit didominasi oleh jenis leguminosa seperti, pueraria javanica dan sejenisnya yang diduga mengandung gizi yang lebih tinggi dibanding lahan pastura yang didominasi oleh rumput.

Struktur tanah yang terdapat pada lokasi sawit sangat baik karena sering dilakukan pemupukan tanah oleh petani kelapa sawit sehingga kualitas tanah cukup subur dan terjamin untuk pertumbuhan rumput dan leguminosa. Penggembalaan ternak pada lahan kelapa sawit tidak tergolong penggembalaan berat karena populasi ternak pada lahan sawit masih tergolong rendah atau kepemilikan ternak tidak merata.

\section{Ukuran Tubuh dan Bobot Badan Sapi Bali Jantan Berdasarkan Kelompok Umur dan Sistem Pemeliharaan.}

Rataan parameter ukuran tubuh dan bobot badan anak sapi bali jantan umur 1-1,5 tahun dan muda umur 1,5-2 tahun berdasarkan kelompok umur dan sistem pemeliharaan secara statistik tidak menunjukan perbedaan $(\mathrm{P}>0,05)$. Perbedaan yang nyata $(\mathrm{P}<0,05)$ terdapat pada sapi bali jantan dewasa umur 2-3 tahun lahan pastura memiliki ukuran lingkar dada yang lebih tinggi 164,75 $\mathrm{cm}$ dibanding sapi bali jantan dewasa lahan sawit 147,50 $\mathrm{cm}$. Sapi bali jantan dewasa lahan sawit umur 2-3 tahun memiliki ukuran tinggi pinggul yang cenderung lebih tinggi $153,75 \mathrm{~cm}$ dibanding sapi bali jantan dewasa yang dipelihara pada lahan pastura $118,25 \mathrm{~cm}$. Secara umum dapat disimpulkan bahwa anak sapi bali jantan umur 1-1,5 tahun dan sapi bali jantan muda umur 1,5-2 tahun yang dipelihara pada lahan sawit dan lahan pastura tidak menunjukan perbedaan pada ukuran tubuh dan bobot badan. Ukuran lingkar dada pada sapi bali jantan dewasa lahan pastura menunjukan bahwa produktivitas sapi bali dewasa pada lahan pastura lebih tinggi $164,75 \mathrm{~cm}$ di banding sapi bali jantan dewasa lahan sawit $147,50 \mathrm{~cm}$. Ukuran ini mendekati ukuran lingkar dada SNI (2015) sapi bali jantan umur 24-36 bulan kategori bibit kelas I mencapai $179 \mathrm{~cm}$ dan melebihi ukuran SNI kelas II $=158$ $\mathrm{cm}$ dan kelas III $=145 \mathrm{~cm}$.

Ukuran ini juga lebih tinggi dari penelitian Supriyantono et al. (2008) terhadap sapi bali pada tiga daerah di provinsi bali yaitu karang asem, tabanan dan pulukan bali pada umur 2-3 tahun ukuran lingkar dada rata-rata $156,14 \mathrm{~cm}$ dan penelitian Hikmawaty et al. 
(2014) pada populasi sapi bali yang berbeda di BPTU Bali, VBC Kabupaten Baru dan BPTHMT Serading NTB memiliki ukuran lingkar dada sapi bali jantan dewasa lebih rendah berkisar 131-155,2 cm. Tingginya lingkar dada sapi bali jantan dewasa pada lahan pastura menunjukan pertumbuhan kerangka tulang sapi bali dewasa lahan pastura sudah mulai menurun dan proses selanjutnya adalah pertumbuhan daging dan lemak. Sesuai dengan penelitian Hilmawan (2016) pada umur penggemukan sekitar 2-3 tahun tingkat pertumbuhan tulang sudah mulai menurun, dan proses selanjutnya adalah peningkatan bobot daging dan lemak. Tingginya lingkar dada sapi bali jantan dewasa pada lahan pastura menunjukan potensi pertumbuhan daging dan lemak lebih tinggi dibanding lahan sawit sebab ternak sapi jantan dewasa yang dipelihara pada lahan pastura ditunjang oleh kuantitas dan keberagaman jenis pakan yang lebih baik dari lahan sawit walaupun pakan lahan sawit secara kualitas lebih tinggi. Rataan ukuran tubuh dan bobot badan sapi bali jantan berdasarkan kelompok umur dansistem pemeliharaan Tabel 4.

Tinggi pinggul sapi bali jantan dewasa pada lahan sawit (Tabel 4) menunjukan perbedaan yang nyata $(\mathrm{P}<0,05)$. Tinggi pinggul sapi bali jantan dewasa lahan sawit $153,75 \mathrm{~cm}$ dari sapi bali jantan dewasa lahan pastura $118,25 \mathrm{~cm}$ lebih rendah. Tingginya ukuran tinggi pinggul sapi bali jantan dewasa pada lahan sawit menunjukan bahwa aspek produksi, laju pertumbuhan sapi bali jantan dewasa yang dipelihara pada lahan sawit lebih tinggi dari lahan pastura. Hal ini karena sapi bali yang dipelihara pada lahan sawit berada pada kondisi iklim yang nyaman di bawah naungan pohon sawit dan ditunjang oleh pakan yang berkualitas yang bersumber dari tanaman cover crop yang mengandung protein tinggi sehingga menjamin pertumbuhan kerangka tulang pada sapi bali lahan sawit lebih sempurna dibanding lahan pastura.

\section{Ukuran Tubuh dan Bobot Badan Sapi Bali Betina Berdasarkan Kelompok Umur dan Sistem Pemeliharaan.}

Rataan ukuran tubuh dan bobot badan anak sapi bali betina umur 1-1,5 tahun berdasarkan jenis kelamin dan sistem pemeliharaan dapat terlihat bahwa; panjang badan, tinggi pinggul dan bobot badan sapi bali pada lahan pastura berbeda nyata $(\mathrm{P}<0,05)$ dari lahan sawit.Panjang badan anak sapi bali betina yang dipelihara pada lahan pastura lebih tinggi $103,50 \mathrm{~cm}$ dibanding lahan sawit $84,25 \mathrm{~cm}$. Tinggi pinggul anak sapi bali betina yang dipelihara pada lahan pastura $107,00 \mathrm{~cm}$ lebih tinggi dibanding anak sapi bali betina yang dipelihara pada areal lahan perkebunan kelapa sawit 90,75 cm.Rataan ukuran tubuh dan bobot badan berdasarkan jenis kelamin dan sistem pemeliharaan disajikan pada Tabel 5. Panjang badan dan tinggi pinggul yang lebih tinggi pada anak sapi bali betina lahan pastura menunjukan laju pertumbuhan awal anak sapi lahan

Tabel 4. Rataan ukuran tubuh dan bobot badan sapi bali jantan berdasarkan kelompok umur dan sistem pemeliharaan

\begin{tabular}{|c|c|c|c|c|}
\hline \multirow[t]{2}{*}{ Umur (Tahun) } & \multirow[t]{2}{*}{ Parameter } & \multicolumn{2}{|c|}{ Sistem Pemeliharaan } & \multirow[t]{2}{*}{ Rataan } \\
\hline & & Pastura & Sawit & \\
\hline \multirow[t]{7}{*}{$1-1,5$} & Tinggi Pundak (cm) & $97,00 \pm 5,07$ & $99,25 \pm 7,84$ & $97,75 \pm 5,86$ \\
\hline & Panjang Badan $(\mathrm{cm})$ & $96,12 \pm 7,98$ & $110,50 \pm 18,7$ & $100,91 \pm 13,2$ \\
\hline & Lingkar Dada $(\mathrm{cm})$ & $125,43 \pm 8,84$ & $134,50 \pm 7,32$ & $128,45 \pm 9,18$ \\
\hline & Lebar Dada (cm) & $27,81 \pm 1,60$ & $28,00 \pm 0,81$ & $27,87 \pm 1,35$ \\
\hline & Dalam Dada $(\mathrm{cm})$ & $28,68 \pm 2,84$ & $30,25 \pm 1,70$ & $29,20 \pm 2,55$ \\
\hline & Tinggi Pinggul $(\mathrm{cm})$ & $97,50 \pm 5,85$ & $103,75 \pm 4,27$ & $99,58 \pm 6,02$ \\
\hline & Bobot Badan (kg) & $119,12 \pm 23,7$ & $144,75 \pm 27,14$ & $127,66 \pm 26,8$ \\
\hline \multirow[t]{7}{*}{$1,5-2$} & Tinggi Pundak (cm) & $109,00 \pm 5,65$ & $106,50 \pm 6,92$ & $107,12 \pm 6,33$ \\
\hline & Panjang Badan $(\mathrm{cm})$ & $105,50 \pm 7,77$ & $106,66 \pm 7,03$ & $106,37 \pm 6,65$ \\
\hline & Lingkar Dada (cm) & $140,50 \pm 10,6$ & $138,83 \pm 8,99$ & $139,25 \pm 8,63$ \\
\hline & Lebar Dada (cm) & $30,00 \pm 1,41$ & $30,33 \pm 3,38$ & $30,25 \pm 2,91$ \\
\hline & Dalam Dada $(\mathrm{cm})$ & $33,00 \pm 4,24$ & $29,00 \pm 3,79$ & $30,00 \pm 4,03$ \\
\hline & Tinggi Pinggul $(\mathrm{cm})$ & $109,00 \pm 5,65$ & $108,50 \pm 7,60$ & $108,62 \pm 6,78$ \\
\hline & Bobot Badan (kg) & $167,00 \pm 26,8$ & $187,00 \pm 49,9$ & $182,00 \pm 44,3$ \\
\hline \multirow[t]{7}{*}{$2-3$} & Tinggi Pundak (cm) & $117,75 \pm 2,98$ & $115,87 \pm 6,05$ & $116,50 \pm 5,16$ \\
\hline & Panjang Badan $(\mathrm{cm})$ & $129,50 \pm 9,84$ & $127,62 \pm 17,1$ & $128,25 \pm 14,7$ \\
\hline & Lingkar Dada (cm) & $164,75 \pm 10,4 \mathrm{a}$ & $147,50 \pm 11,6 b$ & $153,25 \pm 13,6$ \\
\hline & Lebar Dada (cm) & $35,62 \pm 3,19$ & $35,12 \pm 2,29$ & $35,29 \pm 2,49$ \\
\hline & Dalam Dada (cm) & $37,50 \pm 8,81$ & $32,75 \pm 1,03$ & $34,33 \pm 5,22$ \\
\hline & Tinggi Pinggul $(\mathrm{cm})$ & $118,25 \pm 3,40 \mathrm{~b}$ & $153,75 \pm 27,8 \mathrm{a}$ & $141,91 \pm 28,3$ \\
\hline & Bobot Badan (kg) & $262,00 \pm 51,1$ & $285,62 \pm 41,8$ & $277,75 \pm 44,2$ \\
\hline
\end{tabular}

Keterangan : huruf berbeda pada baris dan kolom yang sama menunjukkan perbedaan nyata pada taraf 5\% 
Kocu et al.

Jurnal Ilmu Produksi dan Teknologi Hasil Peternakan 5 (3): 110-116

Tabel 5. Rataan ukuran tubuh dan bobot badan sapi bali betina berdasarkan kelompok umur dan sistem pemeliharaan

\begin{tabular}{|c|c|c|c|c|}
\hline \multirow[t]{2}{*}{ Umur (Tahun) } & \multirow[t]{2}{*}{ Parameter } & \multicolumn{2}{|c|}{ SistemPemeliharaan } & \multirow[t]{2}{*}{ Rataan } \\
\hline & & Pastura & Sawit & \\
\hline \multirow{7}{*}{$1-1,5$} & Tinggi Pundak $(\mathrm{cm})$ & $104,50 \pm 4,94$ & $86,50 \pm 11,9$ & $92,50 \pm 13,2$ \\
\hline & Panjang Badan (cm) & $103,50 \pm 7,77 \mathrm{a}$ & $84,25 \pm 6,13 b$ & $90,66 \pm 11,5$ \\
\hline & Lingkar Dada (cm) & $138,00 \pm 12,7$ & $112,50 \pm 11,3$ & $121,00 \pm 16,8$ \\
\hline & Lebar Dada $(\mathrm{cm})$ & $29,50 \pm 2,12$ & $25,50 \pm 3,10$ & $26,83 \pm 3,31$ \\
\hline & Dalam Dada (cm) & $30,00 \pm 1,41$ & $25,50 \pm 3,10$ & $27,00 \pm 3,52$ \\
\hline & Tinggi Pinggul (cm) & $107,00 \pm 4,24 \mathrm{a}$ & $90,75 \pm 4,64 b$ & $96,16 \pm 9,32$ \\
\hline & Bobot Badan (kg) & $155,50 \pm 23,3 \mathrm{a}$ & $90,12 \pm 22,30 \mathrm{~b}$ & $111,91 \pm 39,3$ \\
\hline \multirow[t]{7}{*}{$1,5-2$} & Tinggi Pundak (cm) & $109,30 \pm 42,01$ & $103,00 \pm 2,82$ & $108,58 \pm 37,6$ \\
\hline & Panjang Badan (cm) & $122,80 \pm 13,9$ & $97,50 \pm 10,60$ & $119,83 \pm 14,4$ \\
\hline & Lingkar Dada $(\mathrm{cm})$ & $153,60 \pm 11,3$ & $133,00 \pm 5,65$ & $150,83 \pm 12,2$ \\
\hline & Lebar Dada $(\mathrm{cm})$ & $32,80 \pm 3,89$ & $27,50 \pm 3,53$ & $32,33 \pm 3,66$ \\
\hline & Dalam Dada (cm) & $41,00 \pm 10,5$ & $28,00 \pm 0,00$ & $38,83 \pm 10,7$ \\
\hline & Tinggi Pinggul $(\mathrm{cm})$ & $98,90 \pm 30,1$ & $102,00 \pm 7,07$ & $100,25 \pm 27,1$ \\
\hline & Bobot Badan (kg) & $224,00 \pm 26,2 \mathrm{a}$ & $143,50 \pm 30,4 b$ & $214,16 \pm 33,6$ \\
\hline \multirow[t]{7}{*}{$2-3$} & Tinggi Pundak (cm) & $110,15 \pm 5,88$ & $110,53 \pm 4,89$ & $110,34 \pm 5,30$ \\
\hline & Panjang Badan (cm) & $122,84 \pm 11,0$ & $123,61 \pm 14,6$ & $123,23 \pm 12,8$ \\
\hline & Lingkar Dada $(\mathrm{cm})$ & $157,23 \pm 6,37$ & $153,92 \pm 8,23$ & $155,57 \pm 7,40$ \\
\hline & Lebar Dada $(\mathrm{cm})$ & $32,52 \pm 2,54$ & $33,00 \pm 3,69$ & $32,76 \pm 3,11$ \\
\hline & Dalam Dada (cm) & $34,15 \pm 2,67$ & $32,76 \pm 2,68$ & $33,46 \pm 2,71$ \\
\hline & Tinggi Pinggul $(\mathrm{cm})$ & $112,73 \pm 5,02$ & $111,69 \pm 4,98$ & $112,21 \pm 4,93$ \\
\hline & Bobot Badan (kg) & $222,53 \pm 40,6$ & $217,30 \pm 29,4$ & $219,92 \pm 34,9$ \\
\hline
\end{tabular}

Keterangan : huruf berbeda pada baris dan kolom yang sama menunjukkan perbedaan nyata pada taraf $5 \%$

pastura lebih produktif dibanding lahan sawit. Ukuran ini mendekati Standar Nasional Indonesia (2015) bibit sapi bali betina muda umur 18-24 bulan ukuran panjang badan kategori kelas I $=112 \mathrm{~cm}$, dan setara dengan ukuran panjang badan kelas II $=105 \mathrm{~cm}$ dan kelas III $=101 \mathrm{~cm}$ SNI (2015) maka dapat disimpulkan bahwa panjang badan sapi bali betina muda pada lahan pastura sudah sesuai (SNI) bibit sapi bali kelas II dan III. Ukuran tinggi pinggul pada penelitian ini lebih tinggi dari penelitian Supriyantono et al. (2008) pada 3 daerah penghasil bibit sapi bali di provinsi bali yaitu karang asem, tabanan dan pulukan bali pada umur 0-1,5 tahun ukuran tingi pinggul hanya mencapai $(94,30-98,37 \mathrm{~cm})$.

Bobot badan anak sapi bali yang dipelihara pada lahan pastura lebih tinggi $155,50 \mathrm{~kg}$ dibanding anak sapi bali betina yang dipelihara pada lahan sawit memiliki bobot badan rendah $90,12 \mathrm{~kg}$. Ni,am et al. (2012) menyatakan bahwa dengan bertambahnya bobot badan maka bertambah pula ukuran lingkar dada dan sebaliknya, bertambah lingkar dada maka bertambah pula bobot badan sesuai dengan umur, bobot badan menunjukan volume dan tinggi pinggul menunjukan tinggi. Ukuran bobot badan berkaitan dengan faktor lingkungan dan sistem pemeliharaan yang digunakan oleh peternak.

Ukuran tubuh sapi bali betina muda umur 1,5-2 tahun yang dipelihara pada lahan pastura dan lahan sawit tidak menunjukan perbedaan. Perbedaan yang nyata $(\mathrm{P}<0,05)$ terdapat pada bobot badan sapi bali betina muda yang dipelihara pada lahan pastura lebih tinggi $224,00 \mathrm{~kg}$ dari lahan sawit $143,50 \mathrm{~kg}$ lebih rendah. Ukuran ini lebih tinggi dari penelitian Hikmawaty (2014) bobot badan sapi bali betina dewasa mencapai bobot 170-207,89 $\mathrm{kg}$. Dirjen PKH (2016) melaporkan bahwa produktivitas yang ditampilkan seekor ternak pada dasarnya merupakan resultante dari potensi genetik, pengaruh lingkungan dan interaksi genotif-lingkungan. Tingginya produktivitas sapi bali pada lahan pastura sebab lahan pastura diberikan suplementasi tambahan berupa rumput unggul; Rumput Gajah (pennisetum purpureum) Rumput Raja (King grass) dan mencari rumput lapangan sebagai tambahan.

\section{KESIMPULAN}

Sapi bali yang dipelihara pada lahan pastuara memiliki produktivitas yang lebih tinggi terutama bobot badan dan tinggi pinggul. Produktivitasyang lebih tinggi padalahan pastura karena pemberian suplementasi tambahan rumput unggul yakni Rumput Gajah (Penisetum purpureum) dan Rumput Raja (King grass). Secara umum sapi bali yang dipelihara pada kedua areal yang berbeda memiliki produktivitas yang baik kareana daya dukung lahan tinggi dan populasi ternak masih rendah.

\section{DAFTAR PUSTAKA}

Amad AM, Made S. 2002. Perancangan Percobaan dengan 
Aplikasi SAS dan Minitab. IPB Press. Edisi ke 2 Juli 2002.

Abdullah L. 2006. The development of integrated forage production system for ruminants in rainy tropical regions: the case of research and extensions activity in Java, Indonesia. J Bull Fac Agric Nigata Univ. 58:125-128.

BQA N. 2014. Handling catle trougth high heat humidity indexes. Nebraska University, lincolin

[BPS] Badan Pusat Statistik. 2016. Keerom Dalam Angka. Kerja sama badan pusat statistik dengan BAPPEDA Kabupaten Keerom. Papua (ID): [diunduh 2017 Des 17].

Darmadja, D.S.G.N. 1980. Setengah Abad Peternakan Sapi Tradisional dalam Ekosistem Pertanian di Bali. Disertasi tidak diterbitkan. Universitas Padjadjaran, Bandung.

[Ditjen PKH] Ditjen Bina Produksi Peternakan. 2016. Pedoman Pelaksanaan Budidaya Ternak Ruminansia Potong. Jakarta (ID): Departemen Pertanian.

Fajar M. Y. Isroli. 2014. Perbedaan Respon Fisiologis dan Daya Tahan Panas sapi potong. Nasional unsoed 2015

Farizaldi. 2011. Produktivitas Hijauan Makanan Ternak pada Lahan Perkebunan Kelapa Sawit Berbagai Kelompok Umur di PTPN 6 Kabupaten Batang Hari Provinsi Jambi. Journal Ilmu-ilmu peternakan Vol. XIV. No. 2. (ID) Universitas Jambi.

Handoko. 1995. Klimatologi Dasar, landasan pemahaman fisika atmosfer dan unsur-unsur iklim. Jakarta (ID): PT. Dunia Pustaka Jaya

Halls H, Rummel, Southwel. 1964. Forage and cattle management in Longleaf Slaash Fine Forest. Farmer's Buletin. 21-99.

Hasan S, Natsir A. 2012. Changes in chemical and Physical Condition of Marginal Land Planted With There Strata Forage System. Bul.Penel Hal.29 Unhas Vol.11

Hikmawaty, Gunawan A, RR Nor. Jakaria.2014. Identifikasi Ukuran Tubuh dan Bentuk Tubuh Sapi Bali di Beberapa Pusat Pembibitan Melalui Pendekatan Analisis Komonen Utama. Jurnal Ilmu Produksi dan Teknologi Hasil Ternak. ISSN 2303.2227 Hal 231-237.

Hilmawan F. 2016. Pertumbuhan dan Morfometrik Tubuh ternak sapid an Peranakan Ongole dan Kerbau Jantan dengan Pencitraan Digital. (Tesis). Bogor (ID) : Institut Pertanian Bogor.

Hoda A. 2002. Potensi pengembangan sapi potong pola uasaha tani terpadu di wilayah Maluku Utara (Tesis). Bogor (ID): 2006. Institut Pertanian Bogor.

Kencana S. 2000. Habitat rusa timor (Cervus timurensis) dan kapasitas tampung padang alam Taman Buru Rumberpon. Manokwari [Internet]. [di unduh 2016 Mei 5]. Tersedia pada: http://papuaweb.org/unipa/ dlib-s 123/kencana.

Ni,am M, Purnomoadi A, Dartosukarno S. 2012. Hubungan antara Ukuran-Ukuran Tubuh dengan Bobot Badan Sapi Bali Betina pada Berbagai Kelompok Umur. Animal agricultur journal vol.1 no.1.2012 p541-556

Nurgiantoro. 2002. Statistik terapan untuk penelitian ilmu-ilmu social. Gajah Mada University Press.

Rauf A. 2015. Produktivitas sapi bali pada padang penggembalaan di Kabupaten Bombana. (Tesis). Bogor (ID): Institut Pertanian Bogor.

Reksohadiprodjo, S. 1981. Produksi Hijauan Makanan Ternak Tropik. Penerbit Fakultas Ekonomi. UGM Yogyakarta.

Rusdin, M. Ismail, S. Mustaring, S. Purwaningsih, A. Andriana, Dewi SU. 2009. Studi potensi kawasan lore tengah untuk pengembangan sapi potong. Penelitian ini bekerja sama dengan balitbang provinsi Sulawesi Tengah dan Untad Palu.

SNI [Standard Nasional Indonesia] Sapi Bali Nomor 7651.4:2015. Badan Standarisasi Nasional.

SNI [Standard Nasional Indonesia] Sapi Bali Nomor 7355:2008. Badan Standarisasi Nasional.

Supriyantono A, Lukman H, Suyadi, ismudiono. 2008. Performansi sapi bali pada tiga daerah di Provinsi Bali.Berk. Panel Hayati 13 (147-152)

Thalib C. 2002. Sapi bali di daerah sumber bibit dan peluang pengembangannya. Bogor (ID). Balai Penelitian Ternak hlm 104-105.

Taufan P.2014. Potensi hijauan di perkebunan kelapa sawit sebagai pakan sapi potong di Kabupaten kutaikartanegara. Jurusan Peternakan Fakultas Pertanian Universitas Mulawarman Samarinda.

Yani A \& B.P. Purwanto. 2006. Pengaruh iklim mikro terhadap respons fisiologis sapi peranakan Fries Holland dan modifikasi lingkungan untuk meningkatkan produktivitasnya. Media Peternakan April 2006, hlm35-46 Vol 29 No.1. Departeemen Ilmu Produksi dan Teknologi Peternakan. Fakultas Peternakan IPB.

Yoku O, Supriyantono A, Widayanti T, Sumpe I. 2014. Produksi padang penggembalaan alam dan potensi pengembangan sapi bali dalam mendukung program kecukupan daging di Papua Barat. Pastura Vol.3.No.2:102-105. (ID). Universitas Papua. 